\title{
Abnormal Eating Behaviors among Medical Students at a University in Southern Santa Catarina, Brazil
}

\author{
Prevalência de Transtornos de \\ Comportamentos Alimentares entre \\ Estudantes de Medicina de uma Universidade \\ do Sul de Santa Catarina, Brasil
}

Vivian Comelli Alberton ${ }^{I}$ Márcio José Dal-Ból

Anna Paula Piovezan ${ }^{I I}$

Rosemeri Maurici da Silvall

\section{KEYWORDS: \\ - Eating disorders; \\ - Eating behavior; \\ - Medical students.}

\section{PALAVRAS-CHAVE:}

- Transtornos alimentares;

- Comportamento alimentar;

- Estudantes de Medicina.

Recebido em: 27/03/2012

Reencaminhado em: 06/07/2012 Reencaminhado em: 09/10/2012 Reecaminhado em: 20/11/2012 Aprovado em: 02/12/2012

REVISTA BRASILEIRA DE EDUCAÇ̄̃o MÉDICA $15 \frac{17(1): 15-20 ; 2013}{37}$
I University of Southern Santa Catarina, Tubarão, Santa Catarina, Brazil.

"I Post-Graduation on Health Sciences Program, University of Southern Santa Catarina, Brazil. 


\section{INTRODUCTION}

Eating disorders (ED) - anorexia nervosa (AN), bulimia nervosa (BN) and binge eating disorder (BED) - are behavioral syndromes whose diagnostic criteria have been widely studied over the past thirty years ${ }^{1,2}$. The media conveys the message of beauty and happiness associated with a lean body and generates extreme concern with weight and body shape, which certain individuals try to adapt to in order to be accepted and appreciated. This is a major cause for the development of EDs, especially in women ${ }^{2,3}$. However, other studies indicate the complexity of the interactions among other factors, and these may increase the chance of development, precipitate the onset or determine the perpetuation of them ${ }^{4,5}$

EDs have a global incidence, and studies show significant prevalence in developed countries like the U.S. ${ }^{6}$, Japan ${ }^{4}$, Norway $^{7}$ and European nations ${ }^{8,9}$, as well as in developing countries like Brazil ${ }^{10}$. These studies indicate an increased incidence of such disorders, mainly related to sociocultural, professional and socioeconomic issues, and young adults are particularly susceptible.

Severe clinical complications are related to EDs, especially involving compromised nutritional status due to the delay in diagnosis or treatment, which can lead to metabolic, endocrine, electrolyte, hematologic, cardiac and renal alterations ${ }^{11,12}$. On the other hand, morbidity and mortality rates associated with ED are also significant and may be associated, for example, with the use of other substances ${ }^{13}$ and even to suicide $\mathrm{e}^{14}$

EDs are increasingly the focus of attention of health professionals, because they lead to personal and social injury. The need to understand the phenomenon, as well as allocation of adequate resources, stimulates the conduct of epidemiological studies. Given the above, the present study aimed to estimate the prevalence of abnormal eating behaviors in medical students at a university in southern Santa Catarina, Brazil.

\section{PATIENTS AND METHODS}

A cross-sectional study was conducted using the data collected from a self-administered questionnaire ${ }^{15}$. All medical school students from the first to the tenth semester enrolled in a university in southern Santa Catarina, Brazil, between August and October 2005, were assessed. They agreed to participate by signing an informed consent form. Failure to fully complete the questionnaire was used as an exclusion criterion. At the day of the questionnaire administrations, during regular class periods in their respective classrooms, with the responsible teacher's consent, subjects were clarified by the researchers about the aims of the study and received instructions to complete the questionnaire. After this, researchers distributed the instrument to be filled by students.

The self-administered questionnaire consisted of questions related to the Eating Attitudes Test-26, from the version translated ${ }^{16}$ and validated ${ }^{17}$ into Portuguese. A pilot test was not performed since EAT scale has been widely used as a standardized self-report measure of symptoms and concerns of eating disorders. EAT-26 total score greater than or equal to 21 denoted the existence of pathological eating attitudes and risk for developing eating disorders, being considered positive for disordered eating patterns.

Additional information about the surveyed subjects included age, gender, course term, height in centimeters and weight in kilograms. The latter two allowed us to calculate the body mass index (BMI) in $\mathrm{Kg} / \mathrm{m}^{2}$ (weight divided by height squared).

The research project was approved by the Human Research Ethics of the University, allied to CONEP, under the number 05.262.4.01.III. Data were entered into Epidata software version 3.1 and analyzed using Epi info version 6.04. The results were presented as absolute numbers and percentages, and associations as prevalence ratio (PR).

\section{RESULTS}

Of the 419 students enrolled, 28 (6.7\%) refused to participate. The final sample consisted of 391 subjects, consisting in $93.3 \%$ from population, being represented by 200 females (51.2\%) and 191 males (48.8\%). Of these, 39 had positive EAT-26 scores (34 females and five males), which corresponds to 10 percent of the surveyed population.

Most participants were younger than 20 years old (70.1\%), had BMI $<25 \mathrm{~kg} / \mathrm{m}^{2}(81.1 \%)$ and were studying within the 6 th and the 10 th semester of the course $(50.9 \%)$.

Table 1 shows the total frequency of the most common answers to the questionnaire and its distribution by gender. Overall, the response option "never" showed the highest frequency among the surveyed subjects. In addition, in 18 out of the 26 questions there was gender-related difference in the proportion of responses. In 17 of them (questions 1 , $3,5-7,10,11,13-21$ and 23), the proportion of men who responded "never" was higher than in the proportion of women who gave the same answer. The most frequent response for question number 9 was "always" and the proportion of men who gave that answer was, again, greater than that of women. 
Table 1

Total frequency of the most common answers to the questionnaire and its distribution by gender (Tubarão-SC, 2009; n= 391).

\begin{tabular}{|c|c|c|c|c|}
\hline \multirow[b]{2}{*}{ Question number } & \multirow[b]{2}{*}{ Answer } & \multirow[b]{2}{*}{ Total $n=391$} & \multicolumn{2}{|c|}{ Gender } \\
\hline & & & $\begin{array}{l}\text { Female } \\
(n=200)\end{array}$ & $\begin{array}{c}\text { Male } \\
(n=191)\end{array}$ \\
\hline 1. I am engaged in dieting behavior. & Never & 143 & 40 & 103 \\
\hline 2. I eat diet foods. & Rarely & 99 & 44 & 55 \\
\hline 3. I feel uncomfortable after eating sweets. & Never & 203 & 72 & 131 \\
\hline 4. I like to eat fat foods. & Sometimes & 142 & 74 & 68 \\
\hline 5. I avoid foods containing sugar. & Never & 138 & 51 & 87 \\
\hline 6. I avoid food with a high carbohydrate content. & Never & 162 & 61 & 101 \\
\hline 7. I am preoccupied with a desire to be thinner. & Never & 128 & 34 & 94 \\
\hline 8. I like my stomach to be empty. & Never & 240 & 115 & 125 \\
\hline 9. I think about burning calories when I exercise. & Always & 101 & 70 & 31 \\
\hline 10. I feel guilty after eating. & Never & 176 & 60 & 116 \\
\hline 11. I am terrified about being overweight. & Never & 139 & 32 & 107 \\
\hline 12. I am preoccupied with the thought of having fat on my body. & Sometimes & 96 & 49 & 47 \\
\hline 13. I am aware of calories content of foods that I eat. & Never & 178 & 70 & 108 \\
\hline 14. I have the impulse to vomit after meals. & Never & 345 & 165 & 180 \\
\hline 15. I vomit after I have eaten. & Never & 367 & 181 & 186 \\
\hline 16. I have gone on eating binges where I feel that I may not be able to stop. & Never & 259 & 117 & 142 \\
\hline 17. I give too much time and thought to food. & Never & 147 & 57 & 90 \\
\hline 18. I find myself preoccupied with food. & Never & 130 & 46 & 84 \\
\hline 19. I feel that food controls my life. & Never & 290 & 128 & 162 \\
\hline 20. I cut my food into small pieces. & Never & 133 & 54 & 79 \\
\hline 21. I take longer than others to eat my meals. & Never & 120 & 52 & 68 \\
\hline 22. Other people think that I am too thin. & Never & 192 & 98 & 94 \\
\hline 23. I feel that others would prefer if I ate more. & Never & 250 & 118 & 132 \\
\hline 24. I feel that others pressure me to eat. & Never & 280 & 135 & 145 \\
\hline 25. I avoid eating when I am hungry. & Never & 278 & 135 & 143 \\
\hline 26. I display self-control around food. & Sometimes & 113 & 65 & 48 \\
\hline
\end{tabular}

Table 2 presents the association of positive EAT-26 with other variables. The proportion of subjects with positive EAT26 scores was higher among females compared to males (PR 6.5), as well as among individuals with $\mathrm{BMI}<25 \mathrm{~kg} / \mathrm{m}^{2}$ than in those with BMI $>25 \mathrm{~kg} / \mathrm{m}^{2}$ (PR 4.5), age less or equal 20 years old (PR 1.3), and $1^{\text {st }}-5^{\text {th }}$ semester (PR 1.7). Among women with positive EAT-26 scores, most were in the age group $<20$ years old; with regard to BMI assessment, most students had normal weight, or were below normal weight. Most overweight or obese students were studying within the sixth and tenth semester (data not shown). 
TABLE 2

Distribution of EAT-26 scores by gender, age,

BMI and study semester

(Tubarão-SC, 2009; n= 391)

\begin{tabular}{|c|c|c|c|}
\hline \multirow[b]{2}{*}{ Variable } & \multicolumn{2}{|c|}{ EAT-26 scores } & \multirow{2}{*}{$\begin{array}{c}\text { PR } \\
\text { (Prevalence } \\
\text { Ratio) }\end{array}$} \\
\hline & $\begin{array}{c}\text { Positive, } \\
\% \text { (n) }\end{array}$ & $\begin{array}{c}\text { Negative, } \\
\%(n)\end{array}$ & \\
\hline \multicolumn{4}{|l|}{ Gender } \\
\hline Female $(n=200)$ & $34(17.0)$ & $166(83.0)$ & 6.5 \\
\hline Male $(n=191)$ & $5(2.6)$ & $186(97.4)$ & \\
\hline \multicolumn{4}{|l|}{ Age (years) } \\
\hline$<20(\mathrm{n}=117)$ & $14(12.0)$ & $103(88.0)$ & 1.3 \\
\hline$>20(\mathrm{n}=274)$ & $25(9.1)$ & 249 (90.9) & \\
\hline \multicolumn{4}{|l|}{ BMI (Kg/m2) } \\
\hline$<25(\mathrm{n}=317)$ & 39 (12.3) & $278(87.7)$ & 4.5 \\
\hline$>25(\mathrm{n}=74)$ & $2(2.7)$ & 72 (97.3) & \\
\hline \multicolumn{4}{|l|}{ Study semester } \\
\hline 1st-5th $(\mathrm{n}=192)$ & 24 (12.5) & $168(87.5)$ & 1.7 \\
\hline 6th-10th $(\mathrm{n}=199)$ & 15 (7.5) & $184(92.5)$ & \\
\hline
\end{tabular}

\section{DISCUSSION AND CONCLUSIONS}

This study reported a significant prevalence of pathological eating attitudes, with risk for the development of eating disorders among medical students at a university in southern Brazil, using the Eating Attitudes Test questionnaire as an assessment tool.

The prevalence of 10 percent found in this study is close to that reported in studies using similar methodology in other countries. In elementary schools in Spain was reported that 9.4 percent of students between 12 and 18 years of age had scores consistent with the presence of altered eating behavior ${ }^{18}$, while among university students in Puerto Rico, with median age of 18.3 years, the percentage for these alterations was 9.6 percent $^{19}$. In other studies, even higher prevalence rates in similar populations were observed. The percentage of elementary school students who are at risk for developing eating disorders in northern Israel was 25.8 percent ${ }^{20}$, while in Greece it was 16.7 percent ${ }^{8}$ and the United States it was about 18 percent, according to a nationwide study ${ }^{21}$. Among university students in the United Arab Emirates, 24.6 percent of a sample study was classified into the category of risk for eating disorders ${ }^{22}$, while in cities of Turkey ${ }^{23}$ and Spain ${ }^{24}$, these scores were 22.8 percent and 17.6 percent, respectively. Finally, a study conducted among medical students in Brazil showed that 5.5 percent of them were at high risk for developing anorexia nervosa ${ }^{25}$, and this percentage is well below of that found in women in this study.
Another important finding of this study was that a high proportion of females or subjects with BMI less than $25 \mathrm{~kg} /$ $\mathrm{m}^{2}$ had positive EAT-26 scores. In studies conducted in Chi$\mathrm{na}^{26}$, the majority of medical students with positive EAT-26 scores were female. Similar results were found among other college students in different countries ${ }^{23,24}$, as well as among younger students ${ }^{8}$. In Brazil, this profile was also observed in relation to binge-type eating disorder in a population-based study of adolescents in Cuiabá, Mato Grosso State, in which the prevalence was also higher in females than in males $^{27}$. With respect to BMI, the results contrast with the findings of other authors who demonstrated that low weight college students had lower EAT-26 scores than those with high weight ${ }^{23}$.

Regarding the possible reasons that this can occur, it was discussed that a positive body image is associated with lower food risk attitudes ${ }^{28}$. It is known, however, that women tend to be more influenced than men by culture and media that idealize thinness as the epitome of beauty. This could explain why in the present study women gave positive answers in greater proportion than men to questions related to thinness, for example, involving control of food intake or weight loss (Table 1). Also, if taken to extremes, such concerns could lead to a situation of stress, which can contribute as a risk factor for developing eating disorders ${ }^{29}$.

Still on this factor, it is argued that health area students, and especially medical students, are subject to stress, which increases over the years because of the course requirements, responsibilities and self-demand. However, according to criteria used in this study positive EAT-26 was associated with initial in relation to the last phase of the course (PR 1.7). Finally, in accordance with other authors ${ }^{30}$, we also found a higher prevalence of eating disorders among female students in early stage of medical school, suggesting that this may be due to the fact that they are closer to the adolescence phase, which is known to be vulnerable to this type of disorder.

Concerning to the limits of the research, it is possible to discuss that the design of the study as cross-sectional study, as well as the instrument of evaluation in form of a self-reported questionnaire, or the statistic test employed in its analysis, may lead to restrictions in event comprehension.

\section{CONCLUSION}

In conclusion, the significant prevalence of eating disorder behaviors among medical students, especially women, suggests the need for further research to identify the causes and to facilitate planning of prevention activities. 


\section{REFERÊNCIAS}

1. Bravender T, Bryant-Waugh R, Herzog D, Katzman D, Kriepe RD, Lask B et al. Classification of Eating Disturbance in Children and Adolescents: Proposed Changes for the DSM-V. Eur Eat Disord Rev. 2010;1:79-89.

2. Miranda GT, Karlis V. Eating Disorders in the Female Patient: Pathophysiology and Treatment Strategies. Oral Maxillofac Surg Clin North Am. 2007;19:173-85.

3. Neumark-Sztainer D, Wall M, Eisenberg ME, Story M, Hannan PJ. Overweight Status and Weight Control Behaviors in Adolescents: Longitudinal and Secular Trends from 1999 to 2004. Prev Med. 2006;43:52-9.

4. Chisuwa N, O'dea JA. Body Image and Eating Disorders Amongst Japanese Adolescents. A Review of the Literature. Appetite. 2010;54:5-15.

5. Croll J, Neumark-Sztainer D, Story M, Ireland M. Prevalence and Risk and Protective Factors Related to Disordered Eating Behaviors Among Adolescents: Relationship to Gender and Ethnicity. J Adolesc Health. 2002;31:166175.

6. Hudson JI, Hiripi E, Pope HG JR, Kessler RC. The Prevalence and Correlates of Eating Disorders in the National Comorbidity Survey Replication. Biol Psychiatry. 2007;61:348-58.

7. Kjelsas E, Bjornstrom C, Götestam KG. Prevalence of Eating Disorders in Female and Male Adolescents (14-15 years). Eat Behav. 2004;5:13-25.

8. Bilali A, Galanis P, Velonakis E, Katostaras T. Factors Associated with Abnormal Eating Attitudes Among Greek Adolescents. J Nutr Educ Behav. 2010;42:292-8.

9. Knez R, Munjas R, Petrovecki M, Paucic-Kirincic E, Persic M. Disordered Eating Attitudes Among Elementary School Population. J Adolesc Health. 2006;38:628-30.

10. Ferreira JES, Da Veiga GV. Eating Disorder Risk Behavior in Brazilian Adolescents from Low Socio-Economic Level. Appetite 2008;51:249-55.

11. Messerli-Bürgy N, Engesser C, Lemmenmeier E, Steptoe A, Laederach-Hofmann K. Cardiovascular Stress Reactivity and Recovery in Bulimia Nervosa and Binge Eating Disorder. Int J Psychophysiol. 2010;78:163-8.

12. CartwrightT MM. Eating Disorder Emergencies: Understanding the Medical Complexities of the Hospitalized Eating Disordered Patient. Crit Care Nurs Clin North Am. 2004;16:515-30.

13. Harrop EN, Marlatt GA. The Comorbidity of Substance Use Disorders and Eating Disorders in Women: Prevalence, Etiology, and Treatment. Addict Behav. 2010;35:392-8.
14. Crow S, Eisenberg Me, Story M, Neumark-Sztainer D. Are Body Dissatisfaction, Eating Disturbance, and Body Mass Index Predictors of Suicidal Behavior in Adolescents? A Longitudinal Study. J Consult Clin Psychol. 2008;76:887-92.

15. Hulley SB, Cummings SR, Browner WS, Grady DG, Newman TB. Delineando a Pesquisa Clínica: Uma Abordagem Epidemiológica. 3th ed. Porto Alegre(BR): ARTMED; 2008.

16. Nunes MA, Bagatini L, Abuchaim AL, Kunz A, Ramos D, Silva JA, et al. Considerações Sobre o Teste de Atitudes Alimentares (EAT-26). Rev ABPAPAL .1994;16:7-10.

17. Bighetti F, Santos CB, Santos JE, Ribeiro RPP. Tradução e Validação do Eating Attitudes Test em Adolescentes do Sexo Feminino de Ribeirão Preto-SP. J Bras Psiquiatr. 2004;53:339-46.

18. Lobera IJ, Candau JR, González MTM, Millán MTM, Sánchez NV, Lozano PL. Análisis de Las Actitudes Alimentarias em Uma Muestra de Adolescentes de Sevilla. Med Clin (Barc). 2009;132:83-8.

19. Reyes-Rodríguez Ml, Franko Dl, Matos-Lamourt A, Bulik Cm, Von Holle A, Cámara-Fuentes LR et al. Eating Disorder Symptomatology: Prevalence Among Latino College Freshmen Students. J Clin Psychol. 2010;66:666-79.

20. Maor Nr, Sayag S, Dahan R, Hermoni D. Eating Attitudes Among Adolescents. Isr Med Assoc J. 2006;8:627-9.

21. Austin SB, Ziyadeh NJ, Forman S, Prokop LA, Keliher A, Jacobs D. Screening High School Students for Eating Disorders: Results of a National Initiative. Prev Chronic Dis. 2008;5(4):A114.

22. Thomas J, Khan S, Abdulrahman AA. Eating Attitudes and Body Image Concerns Among Female University Students in the United Arab Emirates. Appetite. 2010;54:595-98.

23. Sanlier N, Yabanci N, Alyakut O. An Evaluation of Eating Disorders Among a Group of Turkish University Students. Appetite. 2008;51:641-5.

24. Sepulveda AR, Carrobles JA, Gandarillas AM. Gender, School and Academic Year Differences Among Spanish University Students at High-Risk for Developing an Eating Disorder: an Epidemiologic Study. BMC Public Health. 2008;28:102.

25. Souza FGM, Martins MCR, Monteiro FCC, De Menezes Neto GC, Ribeiro IB. Anorexia e Bulimia Nervosa em Alunas da Faculdade de Medicina da Universidade Federal do Ceará - UFC. Rev Psiq Clín. 2002;29:172-80.

26. Liao Y, Knoesen NP, Castle DJ, Tang J, Deng Y, Bookun R. Symptoms of Disordered Eating, Body Shape, and Mood Concerns in Male and Female Chinese Medical Students. Compr Psychiatry. 2010;51:516-23. 
27. Pivetta LA, Gonçalves-Silva RMV. Compulsão Alimentar e Fatores Associados em Adolescentes de Cuiabá, Mato Grosso, Brasil. Cad Saude Publica.2010;26:337-46.

28. Lobera IJ, Ríos PB. Body Image and Quality of Life in a Spanish Population. Int J Gen Med. 2011;25:63-72.

29. Treasure J. Eating Disorders. Medicine. 2008;36:430-5.

30. Riffo P, Pérez MP, González JM, Aranda WC. Prevalência de Conductas de Riesgo de Transtornos del Habito del Comer en Estudiantes de Medicina. Rev Chilena Salud Publica. 2003;7:146-9.

\section{AUTHORS' CONTRIBUTION}

Vivian C. Alberton and Márcio J. Dal Bó were involved in the study's planning and its write. Anna Paula Piovezan was in- volved in data analysis and writing the manuscript. Rosemeri M. da Silva was involved in data analysis, in the writing and reviewing the manuscript.

\section{CONFLICTS OF INTEREST}

The authors declared no conflicts of interest.

\section{CORRESPONDENCE ADDRESS}

Anna Paula Piovezan

Av. José Acácio Moreira, 787

DEHON - Tubarão

CEP. 88704-900 - SC

E-mail: anna.piovezan@unisul.br 